\title{
The effect of feeding triticale and rape seed products on sensory characteristics of broiler meat
}

\section{Józefa Gardzielewska ${ }^{1}$, J. Kortz $^{1}$, Lidia Uziębło ${ }^{2}$, Zofia Tarasewicz ${ }^{2}$ and T. Karamucki}

\author{
${ }^{1}$ Katedra Oceny Produktów Zwierzecych, ${ }^{2}$ Katedra Hodowli Drobiu, Akademia Rolnicza \\ Dr Judyma 24, 71-460 Szczecin, Poland
}

(Received 6 February 1991; accepted 29 November 1991)

\begin{abstract}
The experiment was with 117 broiler chickens divided into five groups: control (soyabean oilmeal as protein feed) and four experimental fed on varied rations of triticale, rapeseed oilmeal and ground rape seed. The chickens were slaughtered at the age of 8 weeks. The carcasses were processed and stored for six months at $-18^{\circ} \mathrm{C}$. Sensory examination was carried out on boiled breast and leg muscles.

Diets containing $50 \%$ triticale and up to $18 \%$ rapeseed oilmeal or $12 \%$ of rape seeds did not negatively affect either palatability or flavour of breast meat and boullions. The flavour of leg muscles was affected negatively when chickens were fed on a $50 \%$ triticale and $12 \%$ rape seeds diet.
\end{abstract}

KEY WORDS: meat quality, chickens, triticale, rape seeds, rapeseed oilmeal

\section{INTRODUCTION}

Triticale and rapeseed oilmeal have become popular in Poland as soya and maize substitutes in broiler feeding (Rutkowski i Gawęcki, 1988a, b). However, some observations have indicated that these feeds negatively affect the palatability and flavour of the meat (Shingari et al., 1976; Tilgner, 1957: Uziębło et al., $1987 \mathrm{a}, \mathrm{b} ; 1988)$.

Since the dietary contents of triticale and rapeseed meal used in the reported experiments were relatively high, it seemed interesting to evaluate the effect of these components at two levels of inclusion and to compare diets containing rapeseed oilmeal and whole ground rape seeds.

\section{MATERIAL AND METHODS}

One hundred and seventeen chickens were randomly divided into control (No. 1-24) and four experimental groups as follows: No. $2-23$, No. $3-24$, No. $4-26$ and No. $5-20$ birds. They received different amounts of triticale,

(C) Institute of Animal Physiology and Nutrition 
TABLE 1

Components and chemical composition of feed mixtures, $\%$

\begin{tabular}{|c|c|c|c|c|c|c|c|c|c|c|}
\hline \multirow{3}{*}{ Indices } & \multicolumn{5}{|c|}{ Starter } & \multicolumn{5}{|c|}{ Finisher } \\
\hline & \multicolumn{9}{|c|}{ Group No } & \multirow[b]{2}{*}{5} \\
\hline & 1 & 2 & 3 & 4 & 5 & 1 & 2 & 3 & 4 & \\
\hline \multicolumn{11}{|l|}{ Ingredients } \\
\hline Ground maize & 41.0 & 14.0 & 11.0 & 8.0 & 8.0 & 36.0 & 10.0 & 15.0 & & \\
\hline Ground wheat & 9.0 & 8.0 & 16.0 & - & - & 25.0 & 14.0 & 15.0 & 9.0 & 15.0 \\
\hline Ground winter triticale & - & 25.0 & - & 42.0 & - & - & 35.0 & - & 50.0 & - \\
\hline Ground spring triticale & - & - & 26.0 & - & 47.0 & - & - & 35.0 & - & 50.0 \\
\hline Soyabean oilmeal & 30.0 & 13.0 & 21.0 & 14.0 & 18.0 & 19.0 & 9.0 & 12.0 & & 11.0 \\
\hline Rapeseed oilmeal & - & 15.0 & - & 13.0 & - & - & 10.0 & - & 18.0 & - \\
\hline Ground rapeseed & - & - & 12.0 & - & 12.0 & - & - & 10.0 & - & 12.0 \\
\hline Fish meal & 3.0 & 4.0 & 4.0 & 5.0 & 5.0 & 4.0 & 3.0 & 4.0 & 3.0 & 4.0 \\
\hline Meat and bone meal & - & - & - & - & - & 2.0 & 2.0 & 3.0 & 3.0 & 2.0 \\
\hline Skimmed milk powder & 2.0 & 2.0 & 3.0 & - & 3.0 & - & - & - & - & - \\
\hline Dried yeast & 3.0 & 3.0 & 3.0 & 2.0 & 3.0 & - & - & - & - & - \\
\hline Fat concentrate "Celat" & 8.0 & 8.0 & - & 8.0 & - & 8.0 & 7.0 & $\ldots$ & 8.0 & - \\
\hline Dehulled oats & - & 4.0 & - & 4.0 & - & - & 4.0 & - & 4.0 & - \\
\hline Grass meal & - & - & - & - & - & 3.0 & 3.0 & 3.0 & 2.0 & 3.0 \\
\hline \multicolumn{11}{|l|}{ Chemical composition } \\
\hline Dry matter & 87.7 & 87.4 & 86.8 & 87.4 & 86.8 & 88.3 & 87.4 & 86.8 & 86.9 & 86.9 \\
\hline Crude protein & 23.1 & 22.7 & 22.0 & 22.1 & 22.2 & 19.8 & 19.3 & 19.3 & 19.2 & 19.7 \\
\hline Ether extract & 3.7 & 3.8 & 5.4 & 4.5 & 6.2 & 4.6 & 4.4 & 6.5 & 5.4 & 6.5 \\
\hline Crude tibre & 4.9 & 5.8 & 5.5 & 5.4 & 4.2 & 4.6 & 4.6 & 4.7 & 4.2 & 4.3 \\
\hline Ash & 7.6 & 6.8 & 6.0 & 7.7 & 7.5 & 6.1 & 6.0 & 5.7 & 6.2 & 5.6 \\
\hline Calcium & 1.4 & 1.2 & 1.2 & 1.3 & 1.6 & 1.1 & 1.0 & 1.0 & 1.0 & 1.0 \\
\hline Phosphorus & 0.8 & 0.8 & 0.8 & 0.9 & 0.9 & 0.6 & 0.7 & 0.6 & 0.8 & 0.6 \\
\hline Metabolizable energy, MJ & 11.7 & 11.7 & 12.3 & 11.7 & 12.4 & 11.8 & 11.8 & 12.4 & 11.5 & 12.1 \\
\hline
\end{tabular}

rapeseed oilmeal and ground rape seeds in the diets (Table 1). The broilers were slaughtered at the age of 8 weeks and the carcasses were processed according to the technology used by the meat industry in Poland. After cooling, the carcasses were packed into plastic bags and stored for six months at $-18^{\circ} \mathrm{C}$.

Sensory analysis was carried out individually on boiled breast and leg muscles. The meat and bouillons were tested after Baryłko-Pikielna's (1975) and Tilgner's (1957) sensory methods by a panel of 5 persons of proven sensory abilities (Polish Standard - 65/A). The meat test included: colour, structure, flavour (intensity and appetite augmentation quality), palatability, tenderness and juiciness. Bouillons were evaluated according to their colour, clarity, flavour and palatability.

Every sample and characteristic was assessed independently and graded using a 5 degree scoring system ( 5 - the best). The results were analysed using simple analysis of variance (Ruszczyc. 1970). 


\section{RESULTS}

The results are summarized in Table 2 . No statistically significant differences between the groups were found for each chracteristic of breast muscles, while in leg muscles the flavour desirability in birds fed a higher level of triticale and rape seed grain (group No. 5) was significantly lower than in control chickens and in birds fed lower levels of these feeds (groups No. 1 and 3, respectively). However, when all eight traits were taken into account, a small but distinct tendency for higher scores of both breast and leg muscles of chickens fed on rapeseed (group No. 3) than of birds fed rapeseed oilmeal (group No. 2) was observed. Only the intensity and desirability of the flavour of breast muscles were scored slightly lower in birds fed on rape seed than on rapeseed meal.

TABLE 2

Scores for cooked breast and leg muscles

\begin{tabular}{|c|c|c|c|c|c|c|c|c|c|c|}
\hline \multirow{3}{*}{ Indices } & \multicolumn{5}{|c|}{ Brcast muscles } & \multicolumn{5}{|c|}{ Leg muscles } \\
\hline & \multicolumn{10}{|c|}{ Group No } \\
\hline & 1 & 2 & 3 & 4 & 5 & 1 & 2 & 3 & 4 & 5 \\
\hline Colour & 3.90 & 3.92 & 3.93 & 3.83 & 3.98 & 3.80 & 3.77 & 3.83 & 3.73 & 3.80 \\
\hline Structure & 3.69 & 3.62 & 3.85 & 3.65 & 3.73 & 3.87 & 3.76 & 3.88 & 3.78 & 3.83 \\
\hline Flavour-intensity & 3.79 & 3.78 & 3.72 & 3.69 & 3.64 & 3.92 & 3.81 & 3.83 & 3.77 & 3.77 \\
\hline Flavour-desirability & 3.91 & 3.92 & 3.90 & 3.80 & 3.79 & $3.93^{a}$ & 3.86 & $3.96^{b}$ & 3.85 & $3.76^{a b}$ \\
\hline Tenderness & 3.45 & 3.46 & 3.53 & 3.48 & 3.39 & 3.78 & 3.80 & 3.90 & 3.74 & 3.89 \\
\hline Juiciness & 3.32 & 3.30 & 3.42 & 3.37 & 3.39 & 3.80 & 3.90 & 3.93 & 3.72 & 3.89 \\
\hline Palatability intensity & 3.50 & 3.41 & 3.48 & 3.48 & 3.49 & 3.61 & 3.75 & 3.72 & 3.61 & 3.72 \\
\hline Palatability-desirability & 3.72 & 3.58 & 3.68 & 3.70 & 3.53 & 3.72 & 3.79 & 3.89 & 3.75 & 3.78 \\
\hline
\end{tabular}

Means with the same letter are significantly different at $P \leqslant 0.05$

The leg muscles of chicken given diet No. 3 with a lower level of triticale and rapeseed scored the highest number of grades 4 for flavour desirability ( Table 3 ).

TABLE 3

Frequency of scores of leg muscle's flavour desirability

\begin{tabular}{lccrrrrrrrrr}
\hline & \multicolumn{1}{c}{ Scores } & & 1 & & 2 & & 3 & & 4 & & 5 \\
\cline { 2 - 12 } & & no & $\%$ & no & $\%$ & no & $\%$ & no & $\%$ & no & $\%$ \\
\hline 2.6 & 3.5 & - & - & 3 & 13 & 1 & 4 & & & 2 & 10 \\
$3.6-3.9$ & 14 & 58 & 12 & 52 & 10 & 42 & 16 & 62 & 16 & 80 \\
$4.0 \quad 4.3$ & 10 & 42 & 8 & 35 & 13 & 54 & 10 & 38 & 2 & 10 \\
\hline Total & 24 & 100 & 23 & 100 & 24 & 100 & 26 & 100 & 20 & 100 \\
\hline
\end{tabular}


Scores for bouillon from breast and leg muscles

\begin{tabular}{|c|c|c|c|c|c|c|c|c|c|c|}
\hline \multirow{3}{*}{ Indices } & \multicolumn{5}{|c|}{ Breast muscles } & \multicolumn{5}{|c|}{ Leg muscles } \\
\hline & \multirow[b]{2}{*}{1} & \multicolumn{9}{|c|}{ Group No } \\
\hline & & 2 & 3 & 4 & 5 & 1 & 2 & 3 & 4 & 5 \\
\hline Clarity & 4.2 & 4.3 & 4.3 & 4.2 & 4.3 & 3.6 & 3.5 & 3.6 & 3.6 & 3.6 \\
\hline Colour & 3.9 & 4.0 & 4.0 & 3.9 & 4.0 & 4.0 & 3.9 & 3.9 & 3.9 & 3.8 \\
\hline Flavour-intensity & 3.7 & 3.7 & 3.7 & 3.7 & 3.7 & 3.9 & 3.8 & 3.8 & 3.7 & 3.7 \\
\hline Flavour-desirability & 3.8 & 3.8 & 3.8 & 3.8 & 3.8 & 3.9 & 3.9 & 3.9 & 3.8 & 3.7 \\
\hline Palatability - intensity & 3.6 & 3.6 & 3.6 & 3.6 & 3.6 & 3.7 & 3.6 & 3.8 & 3.6 & 3.7 \\
\hline $\begin{array}{l}\text { Palatability - } \\
\text { desirability }\end{array}$ & 3.6 & 3.6 & 3.6 & 3.6 & 3.6 & 3.8 & 3.7 & 3.8 & 3.7 & 3.8 \\
\hline
\end{tabular}

Sensory evaluation of bouillons prepared from breast and leg muscles did not reveal any significant effect of the diets (Table 4).

\section{DISCUSSION}

The observations of some workers on the unfavourable influence of triticale and rape seed products on the quality of broiler meat was not confirmed in this experiment. Only in the chickens fed the higher level of triticale and rapeseed did the leg muscles have a significantly less acceptable flavour than from the control birds and chickens fed a lower level of triticale. Feeding full-fat rape seed affects the fat content and fatty acid composition of broilers (Smulikowska et al. 1990). This may explain the slight general tendency for higher meat quality, except flavour, in birds fed on rapeseed than on rapeseed oilmeal. The lower scoring of flavour of leg muscles in chicken fed on the higher triticale and full fat rape seed diet may indicate that some autooxidation of fat could take place during a long period of storage. Fat oxidation results in an undesirable flavour and sensory changes in meat (Działoszyński, 1958).

A dietary level of 12 per cent of rape seed is probably close to the upper acceptable level.

\section{CONCLUSIONS}

Diets containing $50 \%$ triticale an up to $18 \%$ of ground rapeseed oilmeal or $12 \%$ of rape seeds did not negatively affect either palatability or flavour of breast meat and bouillons evaluated after 6 months of storage at $-18^{\circ} \mathrm{C}$.

The flavour of leg muscles was affected negatively when chickens were fed on a $50 \%$ triticale and $12 \%$ rape seed diet. 


\section{REFERENCES}

Baryłko-Pikjelna N., 1975. Zarys analizy sensorycznej żywności. WNT. Warszawa.

Działoszyński L., 1958. Zarys biochemii zwierząt. PWN. Lódź-Poznań

Polska Norma PN-65/A-04021. Metody sprawdzania wrażliwości sensorycznej w zakresie smaku i węchu

Ruszczyc Z, 1970. Metodyka doświadczeń zootechnicznych. PWRiL. Warszawa

Rutkowski A., Gawęcki K., 1988a. Zastosowanie ziarna pszenżyta i żyta w mieszankach dla kurcząt brojlerów. Biul. inf. Przem. Pasz. 27, 26-34

Rutkowski A., Gawęcki K., 1988b. Poekstrakcyjna śruta rzepakowa i grochopeluszka jako zamienniki białka soi w micszankach dla kurcząt rzeźnych z udziałem pszenżyta i żyta. Biul. inf. Przem. Pasz. 27, 35-45

Shingari B.K., Sandha G.S., Gill K.S., Ichhponani J.S., 1976. Nutritive value of triticale (Triticum durum $\times$ Secale cercale) uscd as chick fecd. Indian J. Anim. Sci., 46, 299-302

Smulikowska S., Chibowska M., Wiśniewska J., 1990. Wpływ rzepaku niskoglukozynolanowego - nasion, wytłoku lub śruty poekstrakcyjnej na wydajność, masę tarczycy i skład kwasów tłuszczowych u kurcząt brojlerów. Zesz. probl. IHAR. Rośl. oleiste, 1, 100-106

Tilgner D.J., 1957. Analiza organoleptyczna żywności. Wyd. Przem. Lek. Spoż. Warszawa

Uziębło L., Dańczak A., Tarasewicz Z., Wojdala D., Maćkowiak W., 1988. Próba wykorzystania pszenżyta i rzepaku jako składników mieszanek dla brojlerów. Mat. Konferencji Nauk.-Tech. „Pszenżyto i jego wykorzystanie w produkcji drobiarskiej”. RZD Ostoja, 53-64

Uziçbło L., Dańczak A., Wojdała D., 1987a. Wykorzystanie pszenżyta (triticale) w mieszankach paszowych dla kur nieśnych. Zesz. Nauk. Drob. 4, 55-60

Uziębło L., Zięba J., Witkowski A., Brodacki A., 1987b. Masa ciała i niektóre wskaźniki morfologiczne i histologiczne $\mathrm{u}$ kur żywionych mieszankami $\mathrm{z}$ udziałem śruty rzepakowej $\mathrm{i} u$ ich potomstwa. Zesz. Nauk. Drob. 4, 63-72

\section{STRESZCZENIE}

Ocena sensoryczna mięsa kurcząt brojlerów żywionych mieszankami z udziałem pszenżyta i rzepaku

Doświadczenie przeprowadzono na 117 kurczętach-brojlerach, podzielonych na pięć grup: kontrolną (podstawową paszą białkową była śruta sojowa poekstrakcyjna) i cztery doświadczalne, otrzymujące w dawkach różną ilość pszenżyta, śruty rzepakowej pockstrakcyjnej i mielonych nasion r’epaku. Kurczęta ubito w 8 tygodniu życia i po sprawieniu tuszki przechowywano przez 6 miesięcy w temperaturze $-18^{\circ} \mathrm{C}$. Po rozmrożeniu i ugotowaniu oceniano sensorycznie mięśnie piersiowe i udowe oraz buliony $z$ tych mięśni.

Skarmianie dawek zawierających $50 \%$ pszenżyta i do $18 \%$ poekstrakcyjnej śruty rzepakowej lub do $12 \%$ nasion rzepaku nie wpłynęło ujemnie na pożądalność zapachu mięśni piersiowych i bulionów. Dawki zawierające $50 \%$ pszenżyta i $12 \%$ nasion rzepaku spowodowały pogorszenie smakowitości miçśni udowych. 